International Journal of Linguistics, Literature and Translation

ISSN: 2617-0299 (Online); ISSN: 2708-0099 (Print)

DOI: $10.32996 / \mathrm{ijllt}$

Journal Homepage: www.al-kindipublisher.com/index.php/ijltt

IJLLT

\title{
Literary Translation Analysis of Indonesian Short Story Apel dan Pisau
}

\author{
Lusi Mardiana' $\square$ and Ahmad Jum'a Khatib Nur Ali² \\ 'Student of Master's Degree in Translation Studies, English Department, Gunadarma University, Jakarta, Indonesia \\ 'Lecturer of Master's Degree in Translation Studies, English Department, Gunadarma University, Jakarta, Indonesia \\ $\square$ Corresponding Author: Lusi Mardiana, E-mail: mardianalusi86@gmail.com
}

\section{ARTICLE INFORMATION}

Received: 10 October 2021

Accepted: 20 November 2021

Published: 28 December 2021

DOI: 10.32996/ijltt.2021.4.12.20

\section{KEYWORDS}

Kazakova, Translation Strategies, Literature Work, Literary

Translation, Foreignization,

Indonesian Short Story

\section{ABSTRACT}

Translation allows readers to enjoy literary works from all over the world without being constrained by foreign language mastery. For Producing commensurate literary works, translation strategies are employed to deal with different language systems. This research aims at investigating strategies employed by the translator in translating the Indonesian literary work into English. This Descriptive-Analytical Study has been completed by qualitative and quantitative methods. The data sources used are the Indonesian short story Apel and Pisau by Intan Paramaditha and its translation. The 219 collected data are analyzed by using Kazakova's theory of literary translation. The results in this study indicate that the translator used (1) The Observer Strategy 70,78\% (155 data), (2) The Helper Strategy 23,74 \% (52 data), (3) The Adherent Strategy 3,65 \% (8 data), and (4) The Enlightener Strategy 1,83\% (4 data). The study reveals that the strategy dominantly prevailed is the observer strategy $(70,78 \%)$, and the most dominant approach is unbiased $(74,71 \%)$. Also, it is found that the translation ideology is foreignization, where the translator tries to keep the sense of originality of the author's work.

\section{Introduction}

A short story, which belongs to literature works, is a shorter form of prose fiction than a novel. It carries all intrinsic components consisting of character, plot, setting, theme, and point of view that can be examined in a short time. These days, many translators are fascinated to translate short stories that are well-known in a country. It may make his translation work emerge as a celebrated work in other nations. Translation, then, allows the readers to access the world's literature. The translation makes literature enthusiasts easily enjoy short stories from around the world without being restricted to language acquisition problems.

To create such a decent interpreted work, the translator certainly needs to master the source and target languages frameworks just as the artistic perspectives. According to Das (2004), the translator needs to be skilful both in languages and literature. This implies that the translator should go about as a linguist and a literary expert simultaneously. Understanding the nuances of the literary work well and mastering an ideal rule on both the source language and the target language assist him with delivering a top-notch interpretation effectively. Thus, the first works' meaning, feeling, tone, sound, style, and lingual authority could be delivered well.

Kazakova $(2015$, p. 2843) characterizes literary translation as a unique sort of bilingual revision of a literary work, comprising of several steps, such as understanding the literary aspects - theme, characters, setting, plot - before rendering the work into another language. From the definition, translating literary works is not as simple as rendering another kind of documents into the target text. It is more perplexing as the translator needs to comprehend the entire parts of the literary work before transforming the literary work into another language by considering the original writer's style and ideologies. Literary translation is fundamental in presenting excellent literary works from abroad. The translation failures result in a bad quality of translation that makes the readers fizzle in understanding the original story. Henceforth, as a postgraduate student concentrating on translation, the researcher is curious to invest in exploring strategies utilized by translators in deciphering literary works.

Copyright: (C) 2021 the Author(s). This article is an open access article distributed under the terms and conditions of the Creative Commons Attribution (CC-BY) 4.0 license (https://creativecommons.org/licenses/by/4.0/). Published by Al-Kindi Centre for Research and Development, London, United Kingdom. 
Numerous researchers have done comparative studies on the subject of literary translation. One of them is the study by Aveling (2005), who tried to discover dominant translation strategies utilized by Indonesian essayist Umar Kayam for showing portrayals of American English and Javanese language and way of life in his initial Indonesian-language brief tales, entitled Sri Sumarah dan Cerita Pendek Lainnya in 1975. The analysis uses Vinay and Dalbernet's translation techniques. The result demonstrates that the direct translation is utilized massively, fundamentally literal translation with borrowings from English and borrowings with Indonesian thesaurus for Javanese terminologies. Calque and adaptations are found in not very many rates. The second relevant study is Petrulionè's (2012), whose study is principally founded on two of Joanne Haris' books and their translations in Lithuanian, examining the translation strategies for cultural words. Davis' classification is used as the structure for a definite investigation of the translation strategies. The study results have exhibited that the strategy of localization has been utilized frequently. The significant piece of appropriate names is deciphered considering the phonemic angles and applying Lithuanian syntax rules. A couple of exemptions are made to the names of chronicled/strict characters or names that have the adjusted set up Lithuanian type of the name. Expansion as a source of perspective is constantly used to explain the declarations of non-English. Interpretation systems of coming and changes have been not really determined within the novels underneath analysis. The third relevant research is by Wijayanti and Mirahayuni's (2014), who endeavoured to recognize strategies applied in transforming Lian Gouw's novel entitled Only A Girl into its Indonesian interpretation. The data were dissected by utilizing Baker's translation strategies. The result shows that there were 7 strategies utilized, namely (1) translation by a more general word or superordinate, (2) translation by a more neutral or less expressive word, (3) translation by cultural substitution, (4) translation using a loanword or loanword plus explanation, (5) translation by paraphrase using a related word, (6) translation by paraphrase using unrelated words, and (7) translation by omission. The fourth relevant study is Ardhani's (2015), which objective is to investigate the translation strategies used by the translator in deciphering colloquial articulations in the English text of The Secret Life of Ms. Wiz based on Baker's theory. The result of the study reveals that the translator used some techniques, such are (1) idiom with similar meaning and form (16.7\%), (2) idiom with similar meaning but dissimilar form (33.3\%), (3) translation by paraphrase (38,3\%), (4) translation by omission $(0.8 \%)$, and (4) literal translation (10,8\%). The fifth is Enriquez's (2019) research that specializes in gazing and studying the translator's strategies in rendering Visayan folktales into English. The study pursuits to examine whether the strategies used in the translations of the chosen Visayan legends were as yet ready to convey the musings seen inside the essential follows just as the message of the story. The study outcomes showed that the utilization of the oblique translation strategy became more noteworthy apparent. Among the seven sub-classifications of oblique translation, the deciphered renditions showed the successive utilization of acquiring, rendering, and transformation. The clear utilization of a slanted interpretation was considered utilizing the deciphered type of text. The translation strategies utilized in the English versions were as yet ready to transfer the similar message that the Visayan variant of the folktales contained.

Some of the researches previously mentioned above have one thing in common, namely discussing translations of literary works. However, this research has differences that were not discussed in previous researches. This research is investigating translation strategies in the translation of the Indonesian short story into English by using Kazakova's (2015) theory of literary translation, while previous researches have used theories proposed by Baker, Vinay \& Dalbernet, and Davis. Furthermore, most of the previous studies also used literary works from other countries as the Source Text (ST). In contrast to those researches, the present research uses Indonesian literary work as the Source Text (ST) to be analyzed.

\section{Literature Review}

\subsection{Translation Definition}

Translation, in an easy sense, is the procedure of shifting a text in a source language into a target language. Nonetheless, scientific studies on translation show that it is a more complex procedure. Nida and Taber $(1982$, p. 12) stated that translating means restating the closest natural equivalent of the source-language information in the target language, both in terms of meaning and style. Nida \& Taber's definition emphasizes translation on the use of equivalent text in the target text as the substitution of the source text. Similarly, Bell $(1991$, p. 6) defines translation as the process of replacing information in a source text into information in a target text of an equal text. Additionally, Vinay and Darbelnet (1995) defined that "... translation is concerned with the transmission of information from SL to TL..." (p.170). From the definition, what is being transferred is the message. This is confirmed by Albrecht, who said that "... what is being translated are not "codes" or language but "message" or "texts" (Fawcett, 1997, p. four). Furthermore, Venuti (2000) describes translation as more complicated as a process of negotiation of the linguistic and cultural variations of the foreign text by reducing them and supplying any other set of variations, essentially domestic, drawn from the receiving language and lifestyle to permit the foreign to be obtained there. In contrast, Baker (2011, p. 180) proposed that translation is creating the target text from an angle similar to that of the source text.

In short, translation is a process of analysis, interpretation, and creation that replaces one set of linguistic sources and values for any other. 


\subsection{Literary Translation}

Literary translation consists of the words literary and translation. Literary, based on the Merriam-Webster dictionary definition, is relating to or having the characteristics of humane learning or literature. In contrast, translation is a process of transferring the message of the source text into the target text by paying attention to the style of the original work. Simply, literary translation is rendering the literature products from the source language into the target language. However, translating literary works is not a simple procedure. The following are the definitions and concepts of literary translations proposed by some experts.

Boase-Beier, Fawcett, \& Wilson (2014) mentioned that literary translation means two things, (1) the translation of texts that are held to exhibit literary features and (2) the translation of texts in a literary way. It means that the literary translation is a complex process where the translator transfers not only the source text into the target text physically but also all of the literary aspects of the work. Similarly, Chen (2015) argued that literary translation is a complicated system that requires repeatedly analyzing vocabulary, syntax, semantics, and pragmatic elements of the original works and making artwork processing from the text stage, aesthetic, and cultural dimensions by using the use of a variety of strategies. The translator needs to comprehend the source text first by analyzing the word choices, sentences, meaning, and other elements of the original works before rendering the source text into the target text. So, the translation results are not something radically different from the original one. Furthermore, Kazakova (2015) has been described literary translation as a particular type of translation where the translator passes through some steps to find the natural equivalent source text in the target text by using the translator's knowledge. Hence, the translator needs to transform the story in the source text and pass on the author's unique style, feelings, and culture to create a great translation literary work. In other words, the successful literary translator must act as a "cultural mediator who simultaneously acts as a critic, publisher, editor, librarian, author, literary historian, or literary scholar" (Roign-Sanz and Meylaert, 2018).

From the experts' explanations on the literary translation above, it can be concluded that the literary translation is discovering the explicit message that the original author is attempting to convey by using correct word choices and considering the style, tone, and language of the source text.

There are some distinct kinds of literary translations that may vary from one expert to any other. Catford (1965) classified translation into four types. First, in terms of the levels of languages in translation, there were two types of translation, namely "full" and "partial" translation. In the full translation, all parts of SL are transformed into the TL. While in the partial translation, some parts of $\mathrm{SL}$ are not translated. This second type commonly happens in the literary translation for two reasons - introducing the culture of the source text, and some of the terms are untranslatable. Second, in terms of extent, level, and rank, there were two types of translation: "total" and "restricted" translation. In the total translation, the grammar and the choice of words in the SL are totally replaced by the equal grammar and the choice of words in the TL. While in the restricted translation, the source text is rendered into the target text without changing the grammar and the choice of the words. Another kind of translation was proposed by Vinay and Darbelnet (1995). They divided the translation into two: direct translation and oblique translation. Direct translation is when the source language has the exact equivalence of the target language in terms of lexis morphology and structure. There are three procedures in the direct translation: (1) Borrowing, (2) Calque, and (3) Literal. In comparison, oblique translation is when the direct translation is not working. The procedures that belong to oblique translation are transposition, modulation, equivalence, and adaptation.

\subsection{Kazakova's Literary Translation Strategies}

Literary translations are indispensable in introducing the best literary works from different countries. Readers easily understand the storyline when the works are translated into their native language. In translating literary works, a translator uses many strategies to produce the closest natural equivalent of the source language message. There are a lot of translation strategies proposed by the experts. However, in this study, the data were analyzed by using Kazakova's translation strategies. Kazakova's theory of translation strategies is chosen as the base of the data analysis as it provides the strategies which fit the translation of literary works. It gives more details based on the author's intention, and those provide the output of the strategies which the author proposed.

Kazakova (2015) mentioned that there are two approaches in literary translation: biased and unbiased. The use of the biased approach prevents the readers from experiencing language problems and nurtures the readers by adding information in the target text. The biased approach consists of the helper strategy and the enlightener strategy. The helper strategy is a translation strategy in which more analogues or descriptions are used and use the familiar syntax in the target readers. In contrast, the enlightener strategy is a translation strategy in which long descriptions or commentaries are used. The unbiased approach aims to keep the sentence pattern in the source text and the target text. It consists of the observer-strategy and the adherent strategy. The observer strategy produces literal translation in the target text. At the same time, the adherent strategy result is a word-for-word translation (pp. 2845 - 2846). 
The following are examples of the use of Kazakova's translation strategies.

\subsubsection{Biased Approach}

A. The helper strategy

\begin{tabular}{|l|l|}
\hline \multicolumn{1}{|c|}{ The Source Text } & \multicolumn{1}{c|}{ The Target Text } \\
\hline $\begin{array}{l}\text { Dulu aku ketakutan setengah mati sehingga kusembunyikan } \\
\text { kepalaku di balik bantal bila malam tiba. (p. 141) }\end{array}$ & $\begin{array}{l}\text { The stories scared me half to death and made me bury } \\
\text { my head under my pillow at night. (p. 3) }\end{array}$ \\
\hline
\end{tabular}

Tabel 1. The example of the helper strategy

\section{Analysis:}

From the translation results, it can be seen that the word... dulu... is not translated explicitly in the target text as the target readers would notice it by the use of past tense. Also, the phrase ... bila malam tiba... is rendered into... at night... in the target text. The translator chose the phrase which is more familiar for the target readers. Thus, the translation strategy used is the helper strategy which belongs to the biased approach.

\section{B. The enlightener strategy}

\begin{tabular}{|l|l|}
\hline \multicolumn{1}{|c|}{ The Source Text } & \multicolumn{1}{c|}{ The Target Text } \\
\hline $\begin{array}{l}\text { Kalaupun kucoretkan krayon pada buku gambarku, yang } \\
\text { kugambar adalah loteng kelam dengan harta karun bersinar- } \\
\text { sinar di dalamnya. (p. 142) }\end{array}$ & $\begin{array}{l}\text { Whenever I took my crayons and scrawled in my } \\
\text { colouring book, I'd draw a dark attic that held treasure } \\
\text { gleaming within. (p.4) }\end{array}$ \\
\hline
\end{tabular}

Table 2. The example of the enlightener strategy

\section{Analysis:}

From the translation result, it can be seen that clause... Kalaupun kucoretkan krayon pada buku gambarku... is transformed into.... Whenever I took my crayons and scrawled in my colouring book. The translator added more information for the target readers ... I took my crayons... in the target text. The strategy used is the enlightener strategy which belongs to the biased approach.

\subsubsection{Unbiased Approach}

\section{A. The Observer Strategy}

\begin{tabular}{|l|l|}
\hline \multicolumn{1}{|c|}{ The Source Text } & \multicolumn{1}{c|}{ The Target Text } \\
\hline $\begin{array}{l}\text { Semasa kecilku Ibu selalu berkisah tentang hantu perempuan } \\
\text { yang menghuni loteng rumah kami. (p. 141) }\end{array}$ & $\begin{array}{l}\text { When I was little, my mother used to tell me stories about } \\
\text { a ghost woman who lived in our attic. (p.3) }\end{array}$ \\
\hline
\end{tabular}

Table 3. The example of observer strategy

\section{Analysis:}

From the translation results, it can be concluded that the translator used the observer strategy, which belongs to the unbiased approach where the Indonesian text is the closest form of the source language.

\section{B. The Adherent Strategy}

\begin{tabular}{|l|l|}
\hline \multicolumn{1}{|c|}{ The Source Text } & \multicolumn{1}{c|}{ The Target Text } \\
\hline $\begin{array}{l}\text { Meski begitu, tidak ada yang lebih menggelitik fantasiku } \\
\text { selain cerita misteri. } \\
\text { (p. 141) }\end{array}$ & $\begin{array}{l}\text { Even so, nothing spurred my fantasies more than } \\
\text { mysterious tales. } \\
\text { (p. 3) }\end{array}$ \\
\hline
\end{tabular}

Table 4. The example of the adherent strategy

\section{Analysis:}

From the translation result, it can be seen that the translator produced exactly the same sentence pattern as the source text. The translator used word-for-word translation, which belongs to the adherent strategy.

\subsection{Short Story}

Based on Merriam-Webster dictionary, a short story is an invented prose narrative shorter than a novel, usually dealing with a few characters and aiming at unity of effect and often concentrating on the creation of mood rather than plot. The definition implies at least four characteristics of a short story: (1) Short story is a fiction, it is a created-story, (2) Short story is shorter than a novel, and (3) Short story has implied purpose to harmonize that allows the readers to understand the relationship between the characters in the story, (4) Short story has an arranged structure. 
Similarly, numerous experts have variously defined a short story. First, Poe defined a short story as a brief story that may be told or read at one sitting (Lawrence, 1971, p. 275). This definition requires two matters of the story: (1) that it is short and (2) that it shall own coherence enough to keep the reader's or listener's unflagging interest from start to end. The phrases of the definition are of necessity relative. It is, of the path, impossible to attract a hard and rapid line and say that any story which includes less than so many hundred words is short, while a story that contains one word more than the allocated element is lengthy. Poe's theory is made clear by Matthews in Basseler \& Nünning (2011, p. 45), who stated that a short story is about a single character, a single event, a single feeling, or the collections of feelings known as forth through a single state of affairs. He also strengthened the emphasis on the plot: "the short-story is nothing if there is no story to tell; - one would possibly nearly say that a shortstory is nothing if it has no plot." Another expert affected by Poe's theory was Essewin (1909), who borrowed Poe's unity of effect or impression and emphasized the essence of the plot. According to Essewin in Basseler \& Nünning (2011, p. 46), a short-story is a brief, ingenious narrative, unfolding a single, predominating incident and a single chief character, it includes a plot, the details of which might be so compressed, and the entire treatment so organized, to supply a single impression. Moreover, Scofied in Basseler \& Nünning (2006) described a short story as an appropriate media to express the author's imagination and deliver "metaphoric meaning, symbolism and allegory", which is frequently linked with several (polyvalent) ethical or didactic factors.

Next, Poe classified short stories based on substance and form. First, based on the substance, there are two kinds of a short story, namely "story of fact and the story of fancy. Second, based on the form, there are three kinds of short story, namely "stories told historically, stories told dramatically, stories told didactically". The substance classification reminds us of children's basic understanding of stories that actually happened and seemed to happen. While the form classification shows that a story can be told in one of three ways - historically, dramatically, or didactically. Historically, the short story is used to tell other people that a true story happened in the past. Dramatically means that the short story is delivered to achieve a single effect. While didactically means that the short story is used to teach a lesson.

As it has been stated above, the short story has structures. DiYanni (1990) explained the short story structures through the following diagram:

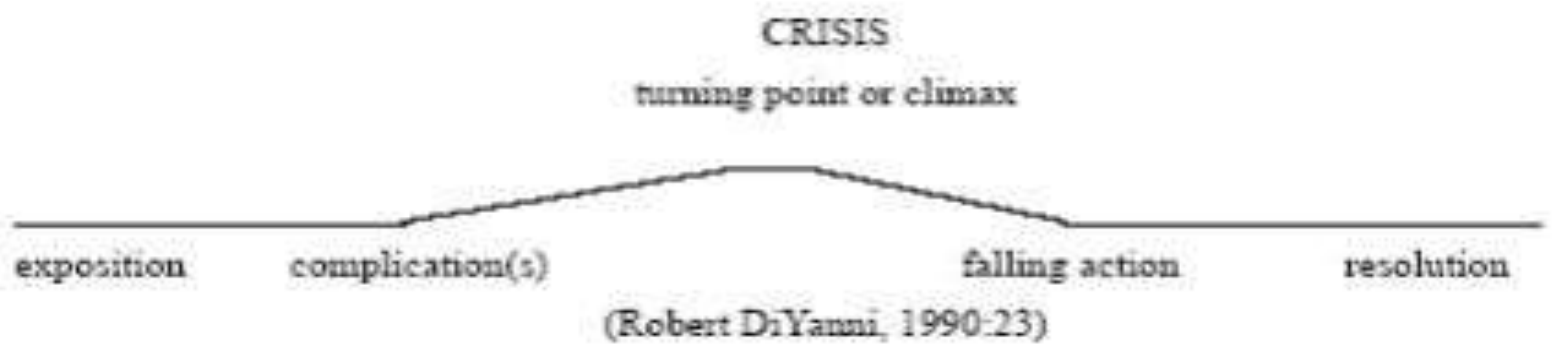

So, it can be seen that the short story's structures consist of exposition, complications, crisis, falling action, and resolution.

\subsection{Translation Ideologies}

Translation consists of several stages. One of the stages is the analysis, which is very important. At this stage, the translator considers two things, namely the target readers and the purpose. Basnett and Lefevere in Hoed (2006) stated that the purpose of the translation reflects the translator's ideology (p. 83). There are two ideologies in translation: foreignization and domestication (Venuti in Hoed, 2006, p.84). Foreignization means retaining the translation like the source text, while domestication means to familiarize the translation into the target language. The use of foreignization may increase the sense of originality of the literary work; however, it could also be very unfamiliar to the target readers. On the other hand, domestication may increase readers' understanding of the target language, yet it might also get rid of the piece's originality.

\subsection{Literary Aspects of the Indonesian Short Story Apel dan Pisau}

The Indonesian short story of Apel dan Pisau belongs to horror fiction. The short story of Apel dan Pisau written by Intan Paramaditha tells a flashback story of a young woman named Eva who turns into a Dracula. One day, when one of her friends offered her a red apple, memories of Cousin July were brought back into her mind. Cousin Juli was the one bewitching her into a Dracula woman thirsting for fresh human blood. The event happened ten years ago when she was seventeen years old. Since then, the smell of fresh human blood has always tickled her nose and made her mouth-watered.

There are two main characters in the short story of Apel dan Pisau, which are Cousin Juli and me (Eva). The first character is I, whose name is Eva. The dominant characteristics of Eva are quiet and observant. In the storyline, there are very rare dialogues involving the character of Eva. The character Cousin Juli has some dominant characteristics, such as calm and cunning. The calm characteristic can be known from the story that every time her husband's family quipped her, the character always replied to them calmly. While 
the cunning characteristic can be concluded from the story that the character invited the whole family to the house and trapped them by the charm of handsome young men who subconsciously kill themselves, at last.

The plot of the story consists of exposition, conflict, rising action, climax, falling action, and resolution. The exposition: The story opens with a conversation between the main character Eva and one of her friends offering her a red apple and telling her that she would like to peel it for her. The conflict: Unexpectedly, the red apple and the knife brought back the dark memories that happened ten years ago. It was about Cousin Juli - the wife of Aziz, her oldest cousin-, her ripe apples and her glinting knife. Cousin Juli was an attractive, open-minded, and calm person. The rising Action: At that time, Cousin Juli worked as a promotion manager for a multinational auto company. Since she was so busy, she often went home late and was frequently absent from family gatherings, social clubs, and recitations. Also, she was reluctant to help in the kitchen. This made her husband's family keep gossiping about her. Her fashion style, which showed her curved body was also the family's attention. The first Climax: Cousin Juli would very soon be divorcing Aziz as she was caught messing with a young man who was boarding at their house, named Yusuf. The first falling action: One day, Cousin Juli called Eva's mother to invite the family to come to her house. Being so curious seeing the young man, the family fulfilled the invitation. There, Cousin Juli welcomed them with great warmth. Dishes were served buffet style from a long table. The two maids brought out the desert. Each of them was given a small plate containing a red apple and a sharply whetted knife. They began to peel their apples with the knives. The second climax: Cousin Juli announced that she would introduce the young man to the family. Soon, all heads turned toward a figure entering the dining room with careful steps. At that time, Yusuf was like a boy idolized by many girls. He radiated child-like appeal. There was something that invited delicate fingers to trace along with them. Their hands did not release their knives. Suddenly, faint sounds from their lips were heard. Cousin Juli, the woman behind the play of apples and knives, observed her victims, still under the spell of their passion, a passion that had stolen in amidst blood and pain. The second falling action: The women willfully scratched deeper, gouging their lust. The women had come together in Cousin Juli's spider web, enveloped in an aroma of meat and fruit, so fresh. She gave a winsome smile. She glanced at the mahogany-skinned angel; then, her eyes turned toward me. I felt fragile and soon fell. Resolution: Cousin Juli said, "your wings are torn; let me patch them.? Like the way I patch my ties with others. Slowly, so slowly, Juli licked her lips.

\section{Methodology}

\subsection{Research Design}

In conducting the study, the researcher employed a Descriptive-Analytical Study as the approach. In the descriptive-analytical study, factual data are analyzed and described to make "a critical evaluation" (Kathori, 2009, pp.2-3). Therefore, the descriptiveanalytical study is a study where the research uses the translation results as the data to give descriptions and critical evaluation of them. By utilizing this methodology, the current researcher attempts to investigate what strategies the translator utilises in deciphering the Indonesian Short Story Apple dan Pisau into English.

Furthermore, the researcher applied mixed methods, namely that of quantitative and qualitative. According to Nunan (1992), qualitative research is process-oriented research, which means that the researcher focuses on analyzing the process of translation from the source text (English) into the target text (Indonesian); Meanwhile, quantitative research is outcome-oriented research, where the researcher focuses on the results of the translation (p. 4). In this study, the qualitative method was done by analyzing what strategies were used by the translator and categorizing the strategies. Then, the quantitative method was done by describing the translation results (the result of the translation made by somebody else) and finding the dominant strategy, approach, and ideology of translation.

\subsection{Source of Data}

The data of this study were taken from the Indonesian short story Apel dan Pisau written by Intan Paramaditha and its translations by Stephen Epstein. The work was published by The Lontar Foundation in 2015. The short story consists of 15 pages with 219 data. The researcher decided to use the Indonesian short story as the data source for two reasons. First, it is interesting to know how the foreign translator renders the Indonesian short story into English. Second, the short story is made by one of the Indonesian best writers, as stated in the part of a note from the publisher ( $p$. viii).

\section{3_Analyzing Data Techniques}

The collected data were analyzed through the following steps. First, the researcher read the Indonesian short story and its translation. Second, the researcher typed the data in a table. Then, the researcher analyzed the data to investigate the translation strategy used by the translator by using Kazakova's theory. After that, the researcher described the analysis of each datum by describing each datum. Finally, the researcher classified and categorized the strategies to decide the translation's dominant strategy, approach, and ideology. 


\section{Results and Discussion}

Having analyzed the 219 data, the researcher found out that the translator used all the strategies Kazakova (2015) proposed. The data are presented in the data tabulation displayed in Table 5.

\begin{tabular}{lcc}
\hline Translation Strategies & Number of Data & Percentage \\
\hline The Observer Strategy & 155 data & $70,78 \%$ \\
The Helper Strategy & 52 data & $23,74 \%$ \\
The Adherent Strategy & 8 data & $3,65 \%$ \\
The Enlightener Strategy & 4 data & $1,83 \%$ \\
\hline
\end{tabular}

Table 5: Kazakova's Translation Strategies Used in the Data

From table 1 above, it can be seen that the observer strategy is used in 155 data $(70,78 \%)$, the helper strategy is used in 52 data $(23,74 \%)$, the adherent strategy is used in 8 data $(3,65 \%)$, and the enlightener strategy in 4 data (1,83\%). The most dominant strategy is the observer strategy. The observer strategy and the adherent strategy belong to the unbiased approach, while the helper strategy and the enlightener strategy belong to the biased approach. Hence, the most dominant approach used is unbiased, namely $74,71 \%$. In addition, the examples of the data analysis can be seen as follow:

\subsection{The observer strategy}

In the Indonesian short story Apel dan Pisau, the observer strategy is the most used strategy by the translator. Of 219 data found, the observer strategy is used in 155 data, or it can be said that $70,78 \%$ of the total data found is included in the observer strategy. Kazakova (2015) stated that "When translating fiction using observer-strategy, the translator usually tends to neutralize stylistic peculiarities of the source text, especially the author's personal preferences" (p. 2845).

Example:

\begin{tabular}{|l|l|}
\hline \multicolumn{1}{|c|}{ The Source Text } & \multicolumn{1}{c|}{ The Target Text } \\
\hline $\begin{array}{l}\text { Selama sepuluh detik aku memandanginya, dengan masa lalu yang } \\
\text { berkecamuk di kepalaku, dengan kekinian yang tak mau pergi. (p. } \\
\text { 153) }\end{array}$ & $\begin{array}{l}\text { For ten long seconds, I gazed at her, the past roiling in } \\
\text { my thoughts, the present refusing to vanish. ( } p . \text { 15) }\end{array}$ \\
\hline
\end{tabular}

Table 6. The observer strategy

\section{Analysis:}

On the datum above, the sentence pattern of the target text is similar to the source text. Thus, the literary translation strategy used is the observer strategy which belongs to the unbiased approach. The translator maintains the author's style and leaves an effect of discursion for the target readers.

\subsection{The Adherent Strategy}

Apart from the observer strategy, the adherent strategy is used. In an easy sense, the product of this strategy is a word-for-word strategy. The emergence of this strategy is only 8 out of 219 data, which is only $3.65 \%$ of $100 \%$. Example:

\begin{tabular}{|c|c|}
\hline The Source Text & The Target Text \\
\hline "Ini pelajaran, Eva," Ibu menasihatiku. (p. 159) & "It's a lesson, Eva," my mother advised me. (p. 20) \\
\hline
\end{tabular}

\section{Analysis:}

Table 7. The adherent Strategy

On the datum above, the sentence pattern of the target text is the same as the source text. It looks like word-for-word translation. Thus, the literary translation strategy used is the adherent strategy which belongs to the unbiased approach. Similar to the observer strategy, the use of this strategy is to keep the originality of the author's style, yet, it raises the strangeness to the target readers

\subsection{The Helper Strategy}

This strategy is the second most used strategy by the translator. This amounts to $23,74 \%$ out of $100 \%$. In more detail, 52 data are included in the helper strategy from the existing 219 data. According to Kazakova (2015), in the helper strategy, the translator used "more analogue or descriptions that are more familiar with the target readers" (p. 2846). Example: 


\begin{tabular}{|l|l|}
\hline \multicolumn{1}{|c|}{ The Source Text } & \multicolumn{1}{c|}{ The Target Text } \\
\hline $\begin{array}{l}\text { "Dulu Aziz dan Juli berantem karena Juli nggak mau nyewain } \\
\text { kamar. Sekarang lihat. Dinaikin ke ranjang tuh laki-laki." (p. 159) }\end{array}$ & $\begin{array}{l}\text { "Aziz and Juli used to argue because Juli didn't want to } \\
\text { rent out the room. And now look. She lures a guy into } \\
\text { her bed" (p. 21) }\end{array}$ \\
\hline
\end{tabular}

Table 8. The helper strategy

\section{Analysis:}

The translation strategy used is the helper strategy which belongs to the biased approach. The translator tends to make the target text to be more familiar for the readers. In here, the passive sentence in the source text... Dinaikin ke ranjang tuh laki-laki ... is translated into active... She lures a guy into her bed... which is more acceptable for the target readers.

\subsection{The Enlightener Strategy}

This strategy is the least used strategy by the translator. This amounts to $1,83 \%$ out of $100 \%$. In more detail, 4 data are included in the enlightener strategy from the existing 219 data.

\begin{tabular}{|c|l|}
\hline \multicolumn{1}{|c|}{ The Source Text } & \multicolumn{1}{c|}{ The Target Text } \\
\hline "Dikasih adik dong, supaya nggak manja." (p. 156) & $\begin{array}{l}\text { "Give her a little brother or sister, so she doesn't get } \\
\text { spoiled." (p. 19) }\end{array}$ \\
\hline
\end{tabular}

Table 9. The enlightener strategy

\section{Analysis:}

The translation strategy used is the enlightener strategy which belongs to the biased approach. The translator gives more information to the target readers. In here, the source text... adik... is translated into... a little brother or sister... in the target text.

This research aims to investigate strategies employed by the translators of the Indonesian short story Apel dan Pisau used to render the work into English. Based on the analysis of data using Kazakova's (2015) theory of literary translation strategies, it is revealed that the translators use all of the strategies in translating the literary work. The four strategies are the observer strategy, the adherent strategy, the helper strategy, and the enlightener strategy. The researcher also found in translating the literary work; The observer strategy is the most dominantly used. The translation results using the observer strategy look like literal translation, where the arrangement of the words in both languages is similar. Although this leaves rigidity for the target readers, the translator tries to maintain the original author's style and the literary aspects so that the message, as well as the emotion that the author wants to share through the storyline, can still be conveyed properly.

After knowing the most predominant strategy applied by the translator, the researcher concluded that the most dominant approach is unbiased $(74,71 \%)$, and the ideology of translation is foreignization. It means that the translator retains the translation results like the original one so the target readers are able to feel the sense of the original work even though it could be very unfamiliar for them due to problems of different language systems and cultures.

\section{Conclusion}

The main purpose of this research is to uncover strategies used by the translator in rendering the Indonesian literary work into English. After analyzing the data taken from the Indonesian short story Apel and Pisau by Intan Paramaditha and its English translation by Stephen Epstein, the researchers can conclude that:

a. The translator employed all of the literary translation strategies proposed by Kazakova were employed by the translator in deciphering the Indonesian short story Apel and Pisau into English.

b. The most dominant strategy is the observer strategy, namely 70,78\% (155 data).

c. The most dominant approach is unbiased.

d. The translation ideology is foreignization.

Although the researcher has attempted to analyze the literary translation analysis of Indonesian short stories, there is still a need for a more comprehensive study about this topic. Readers should also note that the data in this study are relatively small and restricted to the literary translation analysis of an Indonesian short story focused on one of Intan Paramaditha's short stories: Apel dan Pisau and its translation. It would be desirable to conduct further research on the analysis of the literary translation of different short stories and analyze them using different theories. 
Funding: This research received no external funding. This article is fully sponsored by the author.

Conflicts of Interest: The authors declare no conflict of interest.

\section{References}

[1] Ardhani, T. (2015). Translation Strategies Used in The English-Indonesian Translation of The Secret Life of Ms Wiz. UNNES Semarang: Unpublished Dissertation.

[2] Aveling, H. (2005). A Thousand Fireflies in Manhattan: Translation in the Short Story of Umar Kayam. Celt, 5 (2), 87-97.

[3] Basseler, M., \& Nünning, A. (2011). A History of the American Short Story. Genres - Periods - Developments. Trier: WVT.

[4] Bell, R. T. (1991). Translation and Translating: Theory and Practice. Longman.

[5] Boase-Beier, J., Fawcett, A., \& Wilson, P. (2014). Literary Translation: Redrawing the Boundaries. UK: Palgrave Macmillan

[6] Baker, M. (2011). In Other Words: A Course Book on Translation (2nd ed.) Routledge.

[7] Catford, J. C. (1965). A Linguistic Theory of Translation. Oxford University Press.

[8] Chen, H. (2015). Research on Literary Translation Capability and the Construction of Training Mode. International Conference on Education Technology and Economic Management (ICETEM 2015). Atlantis Press.

[9] Das, B. K. (2014). A Handbook of Translation Studies (3 ${ }^{\text {rd }}$ ed.). Atlantic Publishers \& Distributors (P), Ltd.

[10] DiYanni, R. (1990). Literature: Reading Fiction, Poetry, Drama, and the Essay. Pace University.

[11] Enriquez, J. V. S. (2019). A Study on Translation Strategies Used in Visayan Folktales. Online Journal of Communication and Media Technologies, 9 (2), 1-12.

[12] Fawcett, P. (1997). Translation and Language Linguistic Theories Explained. United Kingdom: St. Jerome Publishing.

[13] Hoed, B. (2006). Penerjemahan dan Kebudayaan. Pustaka Jaya.

[14] Kazakova, T. (2015). Strategies of Literary Translation. Journal of Siberian Federal University, Humanities \& Social Sciences 12 (20158), 2842 2847, 2015. DOI: 10.17516/1997-1370-2015-8-12-2842-2847, retrieved on December $3^{\text {rd }}, 2021$.

[15] Kothari, C. R. (2004). Research Methodology: Methods and Techniques (2nd revised ed.). New Delhi: New Age International (P) Ltd.

[16] Lawrence, J. C. (1917). A Theory of the Short Story. The North American Review, 2055 (735), 274-286. https://jstor.org/stable/25121469

[17] Nida, E. A., \& Taber, C. R. (1982). The Theory and Practice of Translation. E. J. Brill.

[18] Nunan, D. (1992). Research Methods in Language Learning. Cambridge University Press.

[19] Paramaditha, I. (2015). Spinner of Darkness and Other Tales. The Lontar Foundation.

[20] Petrulionè, L. (2012). Translation of Culture-Specific Items from English into Lithuanian: the case of Harri's Novels. KALBU STUDIJOS, No. 21. 43-49.

[21] Roig-Sanz, D., \& Meylaerts, R. (2018). Literary Translation and Cultural Mediators Peripheral Cultures. Palgrave Macmillan.

[22] Venuti, L. (2000). The Translation Studies Reader. Routledge.

[23] Vinay, J. P., \& Darbelnet, J. (1995). Comparative Stylistics of French and English: A Methodology for Translation. John Benjamins Publishing.

[24] Wijayanti, D., \&Mirahayuni, N. K. (2014). An Analysis of Translation Strategies for Non-Equivalence Used in Lian Gows Novel Only A Girl and Its Indonesian Versions Only A Girl-Menantang Phoenix. PARAFRASE, 14 (01), 31-37. 